\title{
Kelas Mimpi Entrepreneurship Program for Scavenger Children of Jatipadang
}

\section{Bambang Samiono ${ }^{1}$, Rohita $^{2}$, and Octarina Samijayani ${ }^{3}$}

${ }^{1}$ Management Studies Program, Faculty of Economics and Business, University of Al Azhar Indonesia, Jakarta, Indonesia

${ }^{2}$ Early Childhood Education Studies Program, Faculty of Psychology and Education, University of Al Azhar Indonesia, Jakarta, Indonesia

${ }^{3}$ Electrical Engineering Studies Program, Faculty of Science and Technology, University of Al Azhar Indonesia, Jakarta, Indonesia

\section{Abstract}

Scavengers are one of the biggest social problems for Jakarta. Scavenger areas have existed in Jakarta for a long time such as the Gang Saibun RT 08/09 Jatipadang, South Jakarta. Here, more than 300 scavengers illegally occupy vacant areas owned by the Regional Government. Scavenger children are exposed to problems including 1) economic poverty, and 2) attitude or character problems arising from their negative

Corresponding Author: Bambang Samiono be.samyono@uai.ac.id

Published: 11 November 2020

Publishing services provided by Knowledge E

(c) Bambang Samiono et al. This article is distributed under the terms of the Creative Commons Attribution License, which permits unrestricted use and redistribution provided that the original author and source are credited.

Selection and Peer-review under the responsibility of the IC-HEDS 2019 Conference Committee. environments. In addition to the issues facing outsiders ttempting to aid the scavenger communities, there are additional problems which must be addressed. This study aims to provide a descriptive evaluation of the efforts to implement Kelas Mimpi entrepreneurship programs which seek to empower the scavenger children of Jatipadang, carried out by the Community Service Team at Al Azhar University of Indonesia. The study concludes that the entrepreneurship program was successfully implemented because it combined two integrated programs: 1) Entrepreneur Hard Skills Program (Online Sales Agent); and 2) Soft Skills Program (motivation, character building \& service excellent). Moreover, this program succeeded in providing positive impacts in various measurable ways including 1) economic improvement of participants through online business transactions, 2) improvement of the positive character of participants, and 3 ) increased ability to provide excellent services as online sales agents.

Keywords: entrepreneur, community development, scavenger children

\section{Introduction}

\subsection{Background}

The percentage of poor people in DKI Jakarta in September 2018 reached 3.55\%. This number decreased compared to March 2018 of 3.57\% [1]. However, pockets of poverty still appear in several places in Jakarta, one of which is in the scavenger stall area. These shanties informally emerge and inhabit unmanaged areas such as landfills, riverbanks or land that have not been cultivated by the Regional Government. Some 
notions of waste pickers define them as people who collect and process waste as a market commodity. While some interpret it as a social group whose workers collect or sort items that are deemed useful from garbage, both in the landfill (TPA) or outside the dump. The existence of these scavengers provides a job opportunity for the process of recycling municipal waste. But on the other hand, the negative things are relatively diverse emerge such as problems of settlements, environment, population, order, and other social impacts.

Scavenger stalls in Gang Saibun RT 08/09 Jati Padang are the only scavenger area having a long existence in South Jakarta. They occupy an area of 1,700 M2 owned by an empty regional government with 300 inhabitants dwelling the area for generations. Some social problems have inevitably happened in the region until now; there has not been an integrated solution to overcome their obstacles because it is so complex. Some development and empowerment efforts from various agencies and outsiders have experienced some difficulties in being able to reach these scavenger stalls. The strong resistance on the part of the scavenger groups is the main obstacle, especially the rejection of several power holders in the group. It is not common knowledge that children are assets for them to be exploited to help meet their economic needs [2, 3]. So, not all programs can be trusted and accepted by them.

One of the non-governmental organizations that have long fostered the existence of scavengers in Jatipadang, especially in the range of Saibun Gang is Gemilang Indonesia (GI). $\mathrm{Gl}$ has several programs for scavengers including establishing PAUD, Homeschooling named Qur'anic school, Kelas Mimpi, and Rumah Qur'an. The total number of students studying in several Gl programs was recorded in February 2018 of 259 children. The Kelas Mimpi Program is one of the programs that was initiated by GI with the Tangan Diatas Community in the South Jakarta Region (TDA of South Jakarta). This program is guidance and training for youth scavengers. The specific material provided is entrepreneurship training. The target of this program is 30 children from elementary to high school age dropping out of school or not going to school at all. However, in its development, the program has been running slowly due to a lack of resources, curriculum, and financing problems.

The survey revealed two significant problems faced by scavenger children who joined Kelas Mimpi namely: 1) Economic Problems: this problem has a relationship with poverty which is an unbroken chain. This is because there is no access to formal education due to the inability to finance. The absence of educated and productive personnel leads them to low skill, making it difficult to be accepted in the formal employment sector. In the end, the only work they were able to do was to be a scavenger. 2) Attitude/Character 
Problems: the environment and practice of scavengers create a negative character that occurs in these scavenger children as if they are dependent on other parties, lazy, apathetic, and lack of self-confidence. This character is prone to leading to criminal potential and creates social problems.

\subsection{Solution}

The Al Azhar University of Indonesia (UAl) Community Service Team established partnerships with a third party: Gemilang Indonesia (GI) after examining the obstacles to be able to reach out and foster children of scavengers. Through this partnership pattern involving third parties, it is expected that resistance from the scavenger community can be eliminated. The coaching that they do through Kelas Mimpi can be a very effective entrance to implement the program. Besides, collaboration with the Tangan Di Atas Community of South Jakarta (TDA) will provide more positive and more diverse synergy partnerships to develop appropriate development programs for the children of scavengers.

Meanwhile, the solutions for the problems faced by scavengers who are members of the Kelas Mimpi can be through the program development applied to the new Kelas Mimpi concept in the form of 1). Hard Skill Program: Economic problems are overcome by providing hard skills through the Online Business Entrepreneurship Program as an online Reseller Agent. In this program, scavenger children are taken out of their comfort zones as scavengers by educating them to be able to do business online by utilizing social media. The products to be marketed are products owned by business startup members of the South Jakarta TDA community as well as merchandise donations that have been routinely received by GI. 2) Soft Skill Program: The acquisition of entrepreneurial soft skills in scavenger children is necessary for motivation, character building, and the application of excellent service, to reduce the negative character that exists in scavenger children. This soft skill program does not only aim to shape their positive character from an early age to support attitudes in entrepreneurship, but also equip them with the ability to provide excellent service. Therefore, their consumers will be confident to buy from scavenger children.

This program was acquired because although they are scavengers, they are very familiar with gadgets and social media very well. They are also millennial children who are very familiar with devices. This potential will be utilized to produce more benefits from their ability to socialize the media so that it is more than just for playing. Therefore, it becomes a more useful activity that can even increase their income. Gradually, when 
they succeed, they release their comfort zone to scavenge slowly along with the growth of positive character in themselves.

\section{Methods and Equipment}

\subsection{Methods}

The approach to empowering scavenger's children uses the empowerment method [4] as follow: a) Preparation Phase: preparation of officers and field b) Assessment Phase: identification of problems with partners c) Alternative Planning Program Phase d) Formalization Action Plan Phase e) Program Implementation Phase and finally f) Evaluation Phase. Kelas Mimpi Program is an entrepreneurial hard skill and soft skill program. In the Kelas Mimpi there are 30 children with an age range between 10-18 years. As a pilot project, this program will foster children of productive age between 14-18 years, totaling 10 children. These 10 children were chosen with consideration of productive age and the ability to receive material activities. Next, they will be divided into 2 groups, each consisting of 5 middle and high school-age members. The detailed stages of implementing activities that are adjusted by the method are illustrated in Figure (1) below:

The Kelas Mimpi program is carried out for eight months of Implementation and Evaluation Phase. There is a three-month earlier period in the beginning that is used to do Preparation, Assessment, Alternative Planning Program, Formalization and Action Plan Phase cooperation with GI and TDA. The location of the program implementation is in the Jatipadang region, precisely at the Gemilang Indonesia Office, which is close to the participant location.

\subsection{Equipment}

Participants are provided with a laptop/desktop, internet connection and a website to sell products online as a group work tool. The laptop/desktop will be stored in the GI office, where participants get a briefing. Curriculum and materials for online business skills using social media will be compiled and taught by the UAl community service team and the team of practitioners from TDA of South Jakarta. The material will be given for 6 sessions every 1-2 weeks following 2 evaluation sessions. The curriculum and soft skill motivational materials, positive character building and excellent service 
TABLE 1: Activity Implementation Stage

\begin{tabular}{|c|c|c|c|c|}
\hline NO & ACTIVITY & TIME & OUTPUT & PRODUCT \\
\hline A/B & \multicolumn{4}{|c|}{ PREPARATION \& ASSESSMENT PHASE } \\
\hline 1 & Survey & $\begin{array}{l}2 \\
\text { months } \\
\text { before }\end{array}$ & $\begin{array}{l}\text { The proposing team gets a } \\
\text { partner problem map as a } \\
\text { basis for conceptualization }\end{array}$ & $\begin{array}{l}\text { Map of the problems faced } \\
\text { by scavenger children }\end{array}$ \\
\hline C & \multicolumn{4}{|c|}{ ALTERNATIVE PROGRAM PHASE } \\
\hline 2 & $\begin{array}{l}\text { Collaboration with Strategic } \\
\text { Partners }\end{array}$ & $\begin{array}{l}1 \text { month } \\
\text { before }\end{array}$ & $\begin{array}{l}\text { Collaboration with partners } \\
\text { and strategic partners }\end{array}$ & $\begin{array}{l}\text { Letters of agreement with } \\
\text { partners and strategic } \\
\text { partners }\end{array}$ \\
\hline 3 & $\begin{array}{l}\text { Preparation of Curriculum } \\
\text { and Material for hard skills } \\
\text { and soft skills }\end{array}$ & April & $\begin{array}{l}\text { Compilation of online } \\
\text { business curriculum and } \\
\text { materials (6) and motivation } \\
\text { and character-building (4) } \\
\text { and service excellent (1) }\end{array}$ & $\begin{array}{l}\text { Compilation of online } \\
\text { business curriculum and } \\
\text { materials (6) and motivation } \\
\text { and character-building (4) } \\
\text { and service excellent (1) }\end{array}$ \\
\hline D & \multicolumn{4}{|c|}{ FORMALIZATION ACTION PLAN PHASE } \\
\hline 4 & Selection of participant & May & $\begin{array}{l}\text { The formation of } 2 \text { groups } \\
\text { with } 5 \text { members each }\end{array}$ & $\begin{array}{l}\text { The formation of } 2 \text { groups } \\
\text { with } 5 \text { members each }\end{array}$ \\
\hline 5 & $\begin{array}{l}\text { Dissemination of } \\
\text { Provisioning Materials for } \\
\text { Teachers }\end{array}$ & June & $\begin{array}{l}\text { Teachers and mentor } \\
\text { understanding of program } \\
\text { implementation }\end{array}$ & $\begin{array}{l}\text { WA Group Implementing } \\
\text { team }\end{array}$ \\
\hline 6 & $\begin{array}{l}\text { Material Socialization for } \\
\text { participants }\end{array}$ & June & $\begin{array}{l}\text { Participants' understanding } \\
\text { and motivation regarding } \\
\text { program implementation }\end{array}$ & $\begin{array}{l}\text { WA Group participants \& } \\
\text { Implementing Team }\end{array}$ \\
\hline E & \multicolumn{4}{|c|}{ PROGRAM IMPLEMENTATION PHASE I } \\
\hline \multirow[t]{2}{*}{1} & \multirow[t]{2}{*}{$\begin{array}{l}\text { Provision of hard skill and } \\
\text { soft skill material (stage 1-3) }\end{array}$} & \multirow[t]{2}{*}{ July } & $\begin{array}{l}\text { Participants understand } \\
\text { and can manage social } \\
\text { media/marketplace for } \\
\text { Business }\end{array}$ & $\begin{array}{l}\text { Instagram account for each } \\
\text { group business }\end{array}$ \\
\hline & & & $\begin{array}{l}\text { Participants are motivated } \\
\text { to take part in the program }\end{array}$ & $\begin{array}{l}\text { Enthusiasm and } \\
\text { understanding of partners } \\
\text { for the activities carried out }\end{array}$ \\
\hline 2 & $\begin{array}{l}\text { Stage } 1 \text { Monitoring \& } \\
\text { Evaluation }\end{array}$ & July & & Program progress data 1 \\
\hline $\mathrm{F}$ & \multicolumn{4}{|c|}{ PROGRAM IMPLEMENTATION PHASE II } \\
\hline \multirow[t]{2}{*}{1} & \multirow[t]{2}{*}{$\begin{array}{l}\text { Provision of hard skill and } \\
\text { soft skill material (stage } \\
4-6 \text { ) }\end{array}$} & August & $\begin{array}{l}\text { Participants understand } \\
\text { and can run a simple } \\
\text { business }\end{array}$ & $\begin{array}{l}\text { Participants install financial } \\
\text { applications in their } \\
\text { gadgets }\end{array}$ \\
\hline & & & $\begin{array}{l}\text { Participants can find out } \\
\text { and apply non-verbal and } \\
\text { verbal excellent service } \\
\text { practice in business }\end{array}$ & $\begin{array}{l}\text { Increased ability of } \\
\text { participants' confidence } \\
\text { and communication }\end{array}$ \\
\hline 2 & $\begin{array}{l}\text { Stage } 2 \text { Monitoring \& } \\
\text { Evaluation }\end{array}$ & August & & Program progress data 2 \\
\hline D & \multicolumn{4}{|c|}{ EVALUATION PHASE (3-month Internship \& monitoring and evaluation) } \\
\hline
\end{tabular}

will be provided by the proposing team in parallel for 6 sessions after the hard skill material end on the same day. 


\section{Results}

Participants of the online reseller agent program are children aged 14-18 years of junior high/high school level. Some of those are still in school, and the others are dropped out of school. At first, ten scavenger children wanted to get the program. The online agent reseller program for the scavenger children, members of the Kelas Mimpi, has been running under the schedule of implementation and material offered. Overall, this program shows an increase in both the skills and attitudes of scavenger children. Details of the realization of the program are described as follows:

\subsection{Entrepreneurial Hard Skill Program (Online Reseller Agent):}

Entrepreneurial material for online reseller agents was given for six sessions from July to August 2019. This technical training was provided by expert presenters, the online retail business practitioners, and practitioner lecturers from UAl. The provision of material is made by exposing with examples and direct practice through gadgets or desktop computers. Participants who have been divided into two groups are guided step by step to be able to practice the theories given. The high school level participants look easier to practice the material provided than the junior level participants. Therefore, the high school level participants are obliged to teach and guide their classmates. The issue in the provision of the material is the lack of motivation, concentration, and awareness about the importance of the program at the beginning. However, this obstacle can immediately be minimized because the participants were given business motivation and ice-breaking materials at the beginning of the program. These activities were aimed to solve the constraints of interaction between fellow participants and the implementation team.

\subsection{Soft Skill Entrepreneurship Program (motivation, character building \& excellent service):}

The guidance on character aims to reduce negative attitudes and provides awareness of the importance of positive behavior for participants concerning the social environment or with future consumers in the business. The easy way to do this is to set an example and blend it into an interactive game. It is expected that the participants will indirectly understand how to act and behave so that a positive character is created. Considering the wide range of attitude and character problems, the team agreed to provide material 
specifically to increase self-confidence and good communication skills. Similar obstacles such as participation reluctance and shame also arise in the provision of this soft skill material. However, the implementation team consisting of UAl lecturers and students still showed enthusiasm to encourage them involved in the activity. This program continues until they have the confidence to involve and show their participation. At the end of session 6 , they were challenged to present products they made from recycled materials around them in front of the class. This challenge is to observe how much the progress they made in responding to the excellent service, confidence, and communication materials given. A description of the material given in detail is presented in figure (2) below:

TABLE 2: Distribution of Hard and Soft Skill Materials

\begin{tabular}{|c|c|c|c|c|}
\hline NO & MONTH & ACTIVITY MATERIAL & PRODUCT & PRESENTER \\
\hline \multirow[t]{2}{*}{1} & July & $\begin{array}{l}\text { Hard skill 1: Managing social media } \\
\text { for business (Instagram \& FB) }\end{array}$ & $\begin{array}{l}\text { Instagram account for } \\
\text { each group business }\end{array}$ & Practitioner \\
\hline & & $\begin{array}{l}\text { Soft Skill 1: Business Motivation \& Ice } \\
\text { Breaking }\end{array}$ & & Lecturers \& Students \\
\hline \multirow[t]{2}{*}{2} & July & $\begin{array}{l}\text { Hard Skill 2: Managing Market Place } \\
\text { for Business (Sophee \& Toped) }\end{array}$ & $\begin{array}{l}\text { Sophee \& Tokopedia } \\
\text { accounts for each } \\
\text { group business }\end{array}$ & Practitioner \\
\hline & & $\begin{array}{l}\text { Soft Skill 2: Game to Increase } \\
\text { Confidence }\end{array}$ & & Lecturers \& Students \\
\hline \multirow[t]{2}{*}{3} & July & $\begin{array}{l}\text { Hard Skill 3: Copy Writing for } \\
\text { Business }\end{array}$ & Script for products & Practitioner \\
\hline & & Soft Skill 3: Communication Game & & Lecturers \& Students \\
\hline \multirow[t]{2}{*}{4} & August & $\begin{array}{l}\text { Hards Skill 4: The practice of using a } \\
\text { simple financial application for } \\
\text { business }\end{array}$ & $\begin{array}{l}\text { A free financial } \\
\text { application in the } \\
\text { participant gadget }\end{array}$ & Practitioner \\
\hline & & Soft Skill 4: Service Excellent Game I & & Lecturers \& Students \\
\hline \multirow[t]{2}{*}{5} & August & $\begin{array}{l}\text { Hard Skill 5: Making product photo } \\
\text { for Business }\end{array}$ & $\begin{array}{l}\text { participant product } \\
\text { photo }\end{array}$ & Practitioner \\
\hline & & $\begin{array}{l}\text { Soft Skill 5: Service Excellent Game } \\
\text { II }\end{array}$ & & Lecturers \& Students \\
\hline \multirow[t]{2}{*}{6} & August & Hard Skill 6: Business web & Business Web & Lecturers \\
\hline & & Soft Skill 6: Product Presentation & & Lecturers \& Students \\
\hline
\end{tabular}

\subsection{Evaluation}

After the program completed, several evaluations and assessments are carried out by the implementation team. Those activities were conducted to provide an assessment of several indicators of achievement targets that have been determined at the beginning of the program. The assessment is under the initial conditions of the participants. The rating given is shown in the following figure. 
TABLE 3: Participant Assessment Sheet

\begin{tabular}{l|l|} 
NO & INDICATOR \\
A & $\begin{array}{l}\text { The Entrepreneurship Hard Skill } \\
\text { Program: }\end{array}$ \\
\hline 1 & $\begin{array}{l}\text { Entrepreneurial skills of participants } \\
\text { in doing business online using social } \\
\text { media/market place }\end{array}$ \\
\hline 2 & $\begin{array}{l}\text { The ability of participants as online } \\
\text { reseller agents }\end{array}$ \\
\hline 3 & $\begin{array}{l}\text { Increasing the family economy of } \\
\text { participants (IDR) }\end{array}$ \\
\hline B & $\begin{array}{l}\text { The Entrepreneurship Soft Skill } \\
\text { Program: }\end{array}$ \\
\hline 1 & $\begin{array}{l}\text { The motivation of participants to } \\
\text { change the perception of their } \\
\text { environment }\end{array}$ \\
\hline 2 & $\begin{array}{l}\text { The positive character that } \\
\text { participants have in their daily lives. }\end{array}$ \\
\hline 3 & $\begin{array}{l}\text { The ability to provide excellent } \\
\text { service through communication and } \\
\text { self-confidence }\end{array}$ \\
\hline
\end{tabular}

\begin{tabular}{l} 
EXISTING \\
$50 \%$ \\
\hline $25 \%$ \\
\hline $40 \%$ \\
\hline $25 \%$ \\
\hline
\end{tabular}
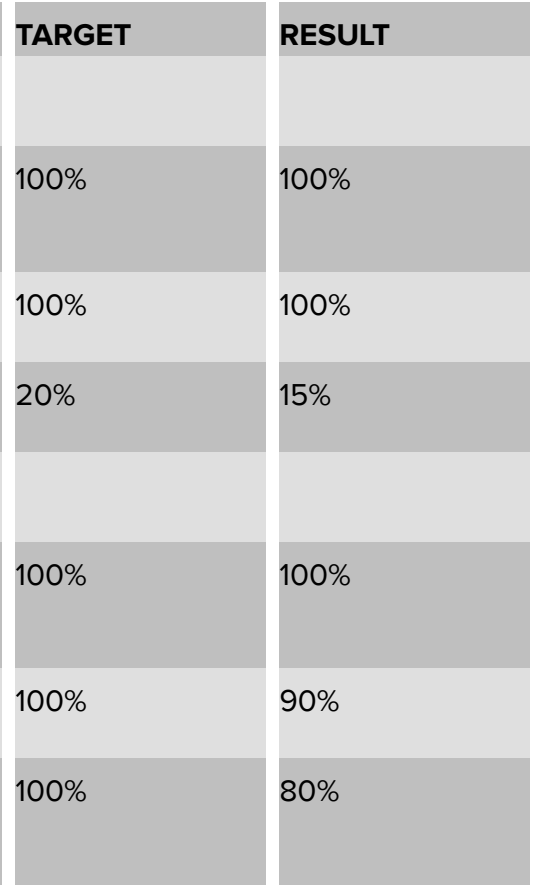

Results of the assessment show that the highest average of achievement occurred in an increase in the hard skills of the participants. The result is comprehensible since it considers the changes occurring are those that refer to technical capabilities. It also shows how the achievement of soft skills needs to be push periodically.

\section{Discussion}

The assessment reveals that the time spent giving material and guidance in practicing the results of the training became a separate obstacle for participants who were still clouds. Longer mentoring time is needed for them to be able to get directly involved in managing this business as well as to change their attitude gradually. The participants need to be assisted continuously through specific business practicing program. In this case, the participant was involved in an internship program under Gemilang Indonesia's Charity Unit for 3 months. They could learn about the online business in this unit since this unit has received donations from donors for their resale through social media in addition to operational funding.

The post-consultation with practitioners will be conducted via the Whatapps group. Otherwise, there will be a monthly post-training meeting. This activity needs to be planned and carried out to keep monitoring so that the results of the internship program still can be implemented properly. It is targeted that within 3 months, there has been 
a business transaction from this online reseller agent business so that participants can feel the results of the program that has been given. The results after 3 months of the internship show that participants in the group were able to generate an average turnover of 13 million per month from the sale of used clothing through online businesses.

Many scavenger empowerments have been carried out as research or community service programs such as empowerment by Wahab (2017) [5] and Rosita (2017) [6]. One of the scavenger empowerment using the e-business implementation method was done by Wahyono (2008) [7] on the scavengers in TPA Jatibarang Semarang. This empowerment project formulates how to increase the selling value of waste pickers using the e-business model. Electronic waste as scavenger products is distributed to fostered SMEs who will sell the product in e-business to have high selling prices. Compared to empowerment in the Kelas Mimpi project in Jatipadang, even though it is the same as using e-business media, the empowerment of scavengers in the TPA Jatibarang Semarang is more about implementing of e-business method for SME partners as the collecting agent not for the scavenger itself. Besides this method is only an implementation plan that has not been applied in practice.

\section{Conclusion}

The Kelas Mimpi Reseller Agent Online Class Program is the right empowerment method to be initiated considering that this program can solve the problem of Jatipadang scavenger children who are members of the Kelas Mimpi related to economic and character problems. The follow-up activity after the training program completed and evaluated is necessary to proceed with the internship program for 3 months. This assistance serves to help participants to be better able to practice the theories, assignments, and materials provided during training in the context of real business. Therefore, this program accomplished what has been targeted. An important thing is the pattern of collaboration between the UAl implementing team with external partners (GI and TDA) is very effective and needs to be used as an empowerment model. Given the difficulty of the community service implementation team directly plunged into the fostered object because of the high resistance from them. There is a need for cooperation with development institutions that directly involved in managing them to gain participation and trust in implementing the program. Moreover, this program succeeded in providing a positive impact such as 1) economic improvement of participants through online business transactions 2) improvement of the positive character of participants and 3) increased ability to provide excellent services as online sales agents. 


\section{Funding}

This work was supported by Simlitabmas DIKTI under Pengabdian Kepada Masyarakat scheme program.

\section{Acknowledgment}

The authors would like to thank their colleagues for their contribution and support to the research. We are also thankful to all the reviewers who gave us valuable inputs to the manuscript and helped in completing the paper.

\section{Conflict of Interest}

The authors have no conflict of interest to declare.

\section{References}

[1] https://jakarta.bps.go.id/pressrelease/2019/01/15/332/tingkat-kemiskinan-danketimpangan2018--di-dki-jakarta-.html.

[2] Sinaga, P. (2008). Kajian Model Pengembangan Usaha di Kalangan Pemulung. Jakarta.

[3] Wiyatna and Putri, M. Y. (2015). Analisi Pengaruh Faktor Sosial Demografi Dan Aktivitas Ekonomi Terhadap Kesejaterahan Keluarga Pemulung di Kota Denpasar. Denpasar: Universitas Undayana.

[4] Adi, I. R. (2015). Kesejahteraan Sosial. Jakarta: PT RajaGrafindo Persada.

[5] Wahab, R. N. (2017). Upaya Pemberdayaan Pemulung Sampah Di Tempat Pembuangan Akhir (Tpa) Desa Pabbentengang Kecamatan Bajeng Kabupaten Gowa. Makassar: Universitas Islam Negri Alauddin Makasar.

[6] Rosita, T. (2017). Pemberdayaan Masyarakat Pemulung Melalui Pengolahan Limbah Di Sungai Citarum. Jurnal IImiah UPT P2M STKIP Siliwangi, vol. 4, issue 2, pp. 12-19.

[7] Wahyono, E. H. (2008). Implementasi E-Business Untuk Sampah Bahan Logam Dan Sampah Kimia. Semarang: DiTPA Jatibarang Semarang. 